\title{
Социальные практики набора в российских вузах
}

\author{
О.А. УРБАН*
}

\begin{abstract}
*Ольга Андреевна Урбан - доктор социологических наук, доцент, заместитель директора, руководитель центра социогуманитарного и информационно-технологического образования, профессор кафедры социологии и философии, Новокузнецкий институт (филиал) ФГБОУ ВО «Кемеровский государственный университет». Адрес: 654041, Новокузнецк, ул. Циолковского, д. 23. E-mail: urban-o@yandex.ru
\end{abstract}

Цитирование: Урбан О.А. (2019) Социальные практики набора в российских вузах // Мир России. Т. 28. № 2. С. 125-147. DOI: 10.17323/1811-038X-2019-28-2-125-147

В соответствии с задачами модернизации системы высшего образования сформирована сеть университетов с особым статусом и дополнительной финансовой поддержкой (федеральные, начиональные исследовательские и опорные), являюшиеся иентрами притяжения для молодежи из разных регионов Российской Федерации. Актуальной проблемой становится изучение сочииальных практик, посредством которых вузы, не имеющие особого статуса, привлекают к поступлению абитуриентов, и насколько эти практики обеспечивают качественный набор абитуриентов, от которого во многом зависит формирование кадрового потенциила экономики и социальной сферы региона. Методологией исследования выбрана разработанная Т.И. Заславской конщепџия соичильных практик.

В статье на основе данных монографического исследования (case study) проводится анализ социальных практик набора и зачисления абитуриентов в российские вузы, целью которых является, с одной стороны, выполнение плановых ицирр приема, с другой, соблюдение нормативных требований к эффективным вузам. Исследование показало институализачию практик, которые обеспечивают выживаемость вуза в текущем периоде, но в то же время порождают системные риски для вуза и потребителя в долгосрочной перспективе. Обосновывается вывод, что данные практики являются неэффективным институтом. В статье предложена система мер, способствующих преодолению негативных последствий возникиих практик и их трансформащии в соответствии с ичелями региональной системы высшего образования.

Ключевые слова: типы вузов, нормативные документы, правила приема в вузы, социальные практики набора, дефицит абитуриентов, качество контингента, риски вуза, риски потребителя 


\section{Введение}

В соответствии с задачами модернизации системы высшего образования (далее ВО) в стране сформирована сеть федеральных (10), национальных исследовательских (29), региональных опорных (33) университетов, которые призваны обеспечить повышение качества и конкурентоспособность российского образования в глобальном образовательном пространстве. С этой целью указанным университетам Федеральным законом от 29.12.2012 г. № 273-Ф3 «Об образовании в Российской Федерации» (ст. 11, п. 10) ${ }^{1}$ предоставлено право разрабатывать и утверждать самостоятельно образовательные стандарты по всем уровням ВО, требования которых не могут быть ниже соответствующих требований Федерального государственного образовательного стандарта (далее - ФГОС) ${ }^{2}$.

Инструментом повышения эффективности ВО стала программа Минобрнауки РФ «Проект 5-100». В октябре 2017 г. Советом по обеспечению конкурентоспособности российских вузов (университетов) ${ }^{3}$ сформированы три группы университетов рейтинга «Проекта 5-100», на поддержку которых до 2020 г. ежегодно планируется выделять до 10 млрд руб. ${ }^{4}$ Всего в рейтинг вошел 21 университет. Объем поддержки программ развития опорных университетов за счет средств федерального бюджета в 2017 г. составил 1,9 млрд руб., a размер софинансирования программ их развития на конец 2017 г. достиг 3,6 млрд руб. [Иванов, Сокол-Номоконов 2018, с. 28]. Критерии, по которым вузы получают особый статус и финансовую поддержку, включая государственное задание, связаны с качеством образования и влиянием на развитие образования, науки и экономики в стране и регионе. Это уровень развития научной деятельности, объем научных исследований и разработок, их трансфер, грантовая деятельность, спектр образовательных программ, количество студентов, аспирантов, научных сотрудников и преподавателей высшей квалификации, диссертаций, защищаемых в университете, международное признание результатов деятельности университета и другое [Иванов, Сокол-Номоконов 2018, с. 26-27; Чубик, Чучалин, Похолков, Агранович 2009, с. 27]. Вместе с тем новые модели университетов [Прохоров 2013, с. 56-66; Шибанова 2015] в системе российского образования отражают процессы иерархической сегрегации, которая приводит к качественным различиям получаемого студентами образования и поддерживается, в том числе, удержанием части вузов на более низких уровнях бюджетного и прочего обеспечения [Сенаменко 2017, с. 11]. В этом плане вузы

\footnotetext{
1 Ф3 от 29.12.2012 г. № 273-Ф3 «Об образовании в Российской Федерации» (в редакции от 29.12.2017 г.) // https://dokumenty24.ru/zakony-rf/zakon-ob-obrazovanii-v-rf.html

2 Качество образования в Ф3 от 29.12.2012 г. № 273-Ф3 «Об образовании в Российской Федерации» (в редакции от 29.12.2017 года) (ст. 2) трактуется как комплексная характеристика образовательной деятельности и подготовки обучающегося, которая выражает степень их соответствия ФГОС, федеральным государственным требованиям и (или) потребностям физического или юридического лица, в интересах которого осуществляется образовательная деятельность, в том числе степень достижения планируемых результатов образовательной программы. В соответствии с Законом ФГОС определяется как основа оценки качества образования.

3 Понятие «вуз» используется в качестве синонима университета.

4 Семь российских вузов вошли в первую группу рейтинга «Проект 5-100» (2017) // ТАСС. 28 октября 2017 // http://tass.ru/obschestvo/4685063
} 
можно разделить на две категории. Первая - вузы с особым статусом, имеющие целевую бюджетную поддержку, источники дополнительного финансирования и ресурсы для предоставления качественного ВО. По оценкам Минобрнауки РФ и согласно данным по числу студентов, обучающихся в ведущих университетах, качественное образование доступно 17\% студентов [Сенашенко 2017, с. 8]. Эти университеты становятся центрами притяжения для молодежи из разных регионов РФ и устанавливают высокие барьеры «входа» абитуриента в ВО. Вторая - вузы, не имеющие особого статуса (традиционные вузы), осуществляющие массовую подготовку квалифицированных кадров для предприятий и субъектов экономической деятельности на территории региона с учетом местной специфики. Так, в процессе мониторинга эффективности ${ }^{5}$ в 2017 г. оценивались результаты деятельности 769 вузов и 692 филиалов ${ }^{6}$, из них только 61 имеют особый статус.

В условиях действия правил приема по результатам ЕГЭ традиционным вузам сложно конкурировать за профориентированного абитуриента с высокими баллами ЕГЭ. В то же время от результатов приемной кампании напрямую зависит как контингент вуза и соответственно рабочие места руководителей и преподавателей, так и формирование кадрового потенциала региона в качестве социального ресурса модернизации экономики [Хадасевич 2012]. Речь идет о подготовке специалистов, обладающих востребованными потребителем компетенциями, необходимыми для эффективного решения текущих и перспективных задач в сфере приложения труда по направлению подготовки, качество которой закладывается уже на этапе набора и зачисления абитуриентов. В этой связи актуальными становятся изучение социальных практик, посредством которых в конкурентных условиях приемной кампании традиционный вуз привлекает к поступлению абитуриентов, и насколько эти практики обеспечивают качественный набор абитуриентов, т.е. наиболее подготовленных к обучению и профессионально ориентированных выпускников образовательных организаций.

\section{Методология исследования}

Концептуализация понятия социальных практик связана с западной социологией (П. Бурдье, Э. Гидденс, Г. Гарфинкель и другие). В работе В.В. Волкова и О.В. Хархордина представлен историко-аналитический обзор исследований в русле теории практик. Авторы, указывая на общий стиль исследований, отмечают их различия в части теоретических положений и используемых понятий [Волков, Хархордин 2008], при этом способ концептуализации варьируется в зависимости от отдельных авторов [Волков 1997, с. 10].

\footnotetext{
5 С 2013 г. - ежегодный мониторинг эффективности деятельности организаций высшего образования, по результатам которого Минобрнауки РФ принимаются решения о реорганизации и закрытии вузов.

6 Информационно-аналитические материалы по результатам проведения мониторинга эффективности деятельности образовательных организаций высшего образования. 2017 год // http://indicators.miccedu.ru/monitoring/2017/index.php?m=vpo
} 
В российской социологии проблематика социальных практик представлена достаточно полно. Данное направление развивается в Европейском университете в Санкт-Петербурге под руководством В.В. Волкова и О.В. Хархордина, которые считают, что «практики конституируют и воспроизводят идентичности или "раскрывают" основные способы социального существования, возможные в данной культуре и в данный момент истории» [Волков, Хархордин 2008, с. 22]. Овладеть практикой - значит овладеть смыслом. Практики осуществляются с использованием особых «инструментов» (тело человека, вещи, знаки, фразы повседневного языка), а человек выступает умелым пользователем [Волков, Хархордин 2008, с. 72]. В.В. Волков указывает на два основных способа понимания практик - «как фонового (неэксплицированного) знания и умения и как конкретной деятельности, соединяющей слова и действия (“языковая игра”)» [Волков 1997, с. 11]. Самое простое понимание фоновой практики - это деятельностный контекст, в котором интерпретируется высказывание или поведение. Социальные трансформации могут быть поняты как изменения не только осознанно-деятельностных, но и неэксплицированных фоновых социальных практик, сопровождающиеся появлением соответствующих идентичностей, формальных институтов и идеологий [Волков 1997, с. 17].

В работах представителей новосибирской экономико-социологической школы социальный институт трактуется как единство формальных и неформальных правил и норм, формой проявления и действия которых является практика повседневной деятельности [Барсукова 2005, с. 118-119; Бессонова 2012, с. 122-123; Заславская 2003, с. 111-120; Кирдина 2014, с. 56; Фадеева 2015, с. 4; Шабанова 2006, с. 71-73]. Социальные практики рассматриваются Т.И. Заславской как конкретные формы функционирования социальных институтов, комплекс которых определяет эффективность (качество) института. Формирование и трансформация института происходит в процессе рутинизации действий. По сути, преобразование институтов - это изменение практик, которое служит самым надежным критерием подлинных институциональных сдвигов [Заславская 2003, с. 111-120]. Позиция Т.И. Заславской сходна с позицией Э. Гидденса, согласно которому практики, обладающие наибольшей пространственновременной протяженностью в рамках тех или иных общностей, рассматриваются как социальные институты. Посредством общепринятых практик, или рутин, т.е. совершаемых в повседневной социальной деятельности привычных действий, социальная жизнь создается и воссоздается во времени и пространстве. Анализ структурации социальных систем означает изучение способов, которыми производятся и воспроизводятся такие системы, основанные на сознательной деятельности акторов, полагающихся на правила и ресурсы во всем многообразии контекстов действия [Гидденс 2005, с. 18, 40, 69-70]. В методологическом плане это означает, что проблемы трансформации социальных институтов следует искать на поведенческом уровне и ориентироваться на изучение повседневной человеческой деятельности, в которой проявляются сложившиеся институциональные правила и поддерживаются не только социальные взаимодействия на микроуровне, но и воспроизводятся (трансформируются) социальные институты на макроуровне.

В работах Т.И. Заславской понятие «социальные практики» трактуется как устойчивые системы взаимосвязанного и взаимноориентированного ролевого поведения акторов (индивидов, организаций, групп), имеющие массовое рас- 
пространение и укорененные в социокультурных нормах. Содержание понятия разворачивается в разделении социальных практик на институционализированные, которые составляют ядро социального института, и неинституционализированные, которые не инкорпорируются в институты. Важным является разделение социальных практик на правовые и неправовые: если в юридической литературе проблема неправовой деятельности рассматривается как противоправное деяние, за которое предусмотрена юридическая ответственность, то в рамках социологического подхода неправовые практики связываются с нарушением формально-юридических и социокультурных норм. Поэтому изучение неправовых практик предполагает сравнение реальных практик как с действующими законами, так и с социокультурными нормами, представлениями о справедливости, сформировавшимися в общественном сознании населения и отдельных его групп [Заславская 2003, с. 209, 219], означающее, что возможны неправовые практики, которые не нарушают закон (нормативные требования). Длительное ослабление институциональных систем может привести к тому, что происходит институционализация неправовых практик, удовлетворяющих потребности конкретных социальных групп в ущерб остальной части общества. Когда реальные практики приобретают устойчиво неправовой характер и становятся нормой, привычной моделью поведения субъектов, происходит мутация института [Заславская 2003, с. 214].

Критерием классификации социальных практик также выступает степень их формализации. В рамках формальных социальных практик функции социальных институтов в конкретных условиях места и времени реализуются в соответствии с существующими законодательными и иными нормативными документами. Неформальные социальные практики базируются на неформальных нормах, которые могут поддерживать нормативно-правовую основу института или вступать в противоречие с ней. В этом случае практики могут перейти в разряд неправовых, даже противозаконных как проявление дисфункционального состояния института.

Причины возникновения и устойчивости неформальных социальных практик, в том числе неправовых, в период трансформации российской экономики интересуют многих исследователей. Социальный механизм их распространения анализируется Т.И. Заславской и М.А. Шабановой [Заславская, Шабанова 2001; Заславская, Шабанова (1) 2002; Заславская, Шабанова (2) 2002]. В работах С.Ю. Барсуковой раскрываются институциональные основы неформальной экономики, ее ценностные основания, обосновываются механизмы теневизации бизнеса, возникновения новых правил взаимодействия власти и бизнеса [Барсукова 2005; Барсукова 2006; Барсукова 2011]. Исследование указанных выше проблем осуществляется и в региональном аспекте [Курбатова, Левин 2003; Курбатова, Апарина, Каган 2009; Курбатова, Левин 2010; Урбан 2010; Урбан 2012 и другие].

Социальные практики в условиях модернизации российского ВО становятся востребованным предметом социологического исследования (новые практики управления вузом, модели поведения преподавателей российских вузов как рефлексивный ответ на сложившуюся ситуацию усиления внешнего контроля над их деятельностью, социальные практики внутри сетевых сообществ и другие) [Курбатова, Донова, Каган 2017; Михайлова, Саввинов 2016; Ромм, 
Заякина 2016]. В осмыслении нуждаются институциональные проблемы ВО в контексте действий и взаимодействий внутри образовательных сообществ в лице административного персонала, научно-педагогических работников и обучающихся. Реальная практика приемных кампаний как комплекс социальных практик по организации конкурсного отбора и зачислению абитуриентов применительно к разным категориям вузов в социологической литературе специально не исследовалась. Между тем на данном этапе могут формироваться кадровые риски развития территорий малопривлекательных для трудоустройства выпускников топовых вузов. Это множество городов с монопрофильной структурой экономики Уральского, Сибирского, Дальневосточного федеральных округов, где кадровый потенциал модернизации формируют преимущественно традиционные вузы.

Для изучения социальных практик и неявных норм, на которых они базируются, в основу положен монографический подход (case study), который определяется как углубленное выборочное исследование какой-либо проблемы на одном отдельно взятом, но представительном объекте. Case study - это эмпирическое исследование, изучающее современный феномен в его реально существующем контексте и предусматривающее применение самых различных методов, и необязательно качественных. Как отмечает И.М. Козина, в методологическом плане работа исследователя похожа на действия исследователя-историка, которому удалось присутствовать самому при интересующем его историческом событии [Козина 1995, с. 65-67].

В течение трех лет в совокупности с влияющими факторами проводилось исследование приемных кампаний вузов Новокузнецка ${ }^{7}$, в которых в 2017 г. обучалось 14190 студентов (27\% от контингента по Кемеровской области $)^{8}$. Предметом исследования определены деятельность и условия деятельности сотрудников вузов в период приемной кампании и выпускников школ в период профессионального выбора. Эмпирический объект исследования - работники образовательных организаций ВО (ответственные секретари приемных комиссий, их заместители, деканы, заведующие кафедрами, преподаватели, работники учебно-методических служб, представители административного аппарата), а также абитуриенты вузов и их родители.

Информационной базой предлагаемых концептуальных обобщений являются нормативные документы, сведения ежегодного (с 2013 г.) мониторинга эффективности деятельности организаций высшего образования, сайты вузов, результаты

\footnotetext{
7 Примечание: вузы Новокузнецка без учета реорганизованных образовательных организаций, которые вели образовательную деятельность до 2016 г.: Сибирский государственный индустриальный университет (далее - СибГИУ), Новокузнецкий институт (филиал) Кемеровского госуниверситета (далее - НФИ КемГУ), Кузбасский государственный технический университет им. Т.Ф. Горбачева в Новокузнецке (далее - КузГТУ в Новокузнецке), Кузбасский институт Федеральной службы исполнения наказания России (Кузбасский институт ФСИН). В апреле 2014 г. по результатам мониторинга эффективности деятельности вузов Кузбасская педагогическая академия вошла в состав Новокузнецкого института (филиала) Кемеровского государственного университета.

8 Рассчитано по данным мониторинга эффективности деятельности образовательных организаций ВО Новокузнецка за 2017 г.: Сибирский государственный индустриальный университет // http://indicators.miccedu.ru/ monitoring/_vpo/inst.php?id=272; Новокузнецкий институт (филиал) Кемеровского государственного университета // http://indicators.miccedu.ru/monitoring/_vpo/inst.php?id=10000305; Филиал Кузбасского технического университета им. Т.Ф. Горбачева в Новокузнецке // http://indicators.miccedu.ru/monitoring/_vpo/inst.php?id=10000358
} 
включенного (участвующего) наблюдения ${ }^{9}$ и неформализованных бесед ${ }^{10}$, данные социологического опроса выпускников школ городов и поселений юга Кузбасса ${ }^{11}$.

\section{Нормативные документы, регламентирующие прием в российские вузы, на базе которых формируются социальные практики}

\section{Ежегодно утверждаемые Минобрнауки РФ правила определяют порядок приема} в подведомственные вузы на обучение по образовательным программам высшего образования - программам бакалавриата, специалитета, магистратуры, в том числе перечень вступительных испытаний при приеме на обучение, льготы при поступлении, порядок поступления иностранных граждан, лиц, имеющих диплом о среднем профессиональном образовании и другое. Основываясь на положениях Минобрнауки РФ, каждый вуз разрабатывает свои правила приема, которые имеют незначительные отличия с учетом особенностей обучения в конкретном вузе.

Вузу выделяются контрольные цифры приема (далее - КЦП) за счет бюджетных ассигнований в соответствии с действующим Порядком. Объем и структура КЦП закрепляют приоритеты и кадровые потребности региональной экономики с учетом возможностей образовательных организаций, самостоятельно распределяющих установленные КЦП по направлениям подготовки и специальностям в рамках укрупненной группы направлений / специальностей. В рамках КЦП вуз может организовывать целевой набор студентов с учетом потребности региональной экономики и социальной сферы в квалифицированных кадрах.

Вуз имеет право принимать на учебу сверх установленного количества КЦП по возмездному договору. В соответствии с ФЗ «Об образовании в Российской Федерации» от 29.12.2012 № 273-Ф3 в сфере образования действует принцип

\footnotetext{
9 Участие автора в подготовке и проведении приемных кампаний вузов в 2007-2012, 2014-2017 гг., имевших различные нормативные основания. Полное включение в ситуацию обеспечивали постоянное присутствие в ней и возможность фиксировать детальную картину процедуры набора и зачисления абитуриентов. Наблюдения проводились за абитуриентами и их родителями при принятии решения выбора образовательной программы, формы обучения и процедуры зачисления, за работой с абитуриентами сотрудников вуза, участвующих в наборе (руководителей образовательных программ, деканов, заведующих кафедрами, работников приемной комиссии). Результаты наблюдений изначально не оформлялись в виде протокола (дневника), в дальнейшем стали делаться заметки.

10 Неформализованные беседы с коллегами и лично знакомыми сотрудниками вузов, которые по своему функционалу владели информацией о специфике приемных кампаний вузов в других городах через участие в различных совещаниях, семинарах секретарей приемных комиссий, давали ценную информацию по соотношению формальных и неформальных процедур в приемной кампании.

11 Социологическое исследование проведено сотрудниками Научно-исследовательской лаборатории социологических исследований Новокузнецкого института (филиала) Кемеровского госуниверситета в январе-феврале 2015 г. по заказу администрации вуза с целью изучения образовательных планов выпускников школ. Генеральная совокупность - 2970 чел. Структура генеральной совокупности - учащиеся 11-х классов учреждений среднего общего образования Новокузнецка, Междуреченска, Осинников, Калтана, Новокузнецкого района. Методом сплошного анкетного опроса всех присутствующих на занятиях были опрошены 2422 учащихся, или $81,3 \%$ от генеральной совокупности. В методическом инструментарии использованы наработки коллег и представлены оригинальные формулировки вопросов. Анкета включала переменные - образовательные планы после окончания школы (направления, профиль подготовки, формы, условия обучения), планы образовательной миграции, мотивы получения ВО, восприятие Новокузнецка как города для получения ВО, источники информации об образовательных организациях ВО, социально-демографические характеристики, успеваемость. Анкеты заполнялись учащимися самостоятельно под контролем интервьюера.
} 
нормативно-подушевого финансирования. Стоимость обучения определяется правительством в соответствии с величиной нормативных затрат по обучению бюджетного студента очной формы. Это фиксированная сумма, ниже которой в подведомственных государству образовательных организаций ВО не могут обучать контрактных студентов, т.е. обучающихся за свой счет. Выделяются несколько стоимостных групп специальностей и направлений подготовки, для которых Минобрнауки РФ определяет базовую стоимость обучения. Согласно Методике определения стоимости обучения в вузе, базовая стоимость умножается на корректирующие коэффициенты, учитывающие региональные особенности ${ }^{12}$.

Большинство вузов набирают абитуриентов по конкурсу на основании трех экзаменов по ЕГЭ, при этом, согласно Приказу № 1 Министерства образования и науки РФ от 9 января 2014 г. (рег. № 31079 от 23 января 2014 г.), учебным заведениям разрешено учитывать результаты лишь двух ЕГЭ (русский язык и профильный предмет по специальности - обязательно).

Мониторинг эффективности деятельности организаций высшего образования включает в себя семь целевых показателей, в том числе дополнительный, который имеет специфику в разных группах вузов (медицинские, творческие и прочие). Общесистемным требованием является выполнение показателя Е.1 «Образовательная деятельность» по среднему баллу ЕГЭ зачисленных абитуриентов на обучение по очной форме не менее 60.

В совокупности нормативные документы федерального значения, регламентирующие правила приема в вузы, предписывают соблюдение условий, обеспечивающих формирование качественного контингента студентов, без которого проблему повышения качества образования решить невозможно.

\section{Дефицит абитуриентов как ключевой фактор формирования специфических практик набора абитуриентов}

Нормативно регулируемый прием в вузы реализуется в комплексе социальных практик, порождаемых в том числе условиями, в которых практики творятся агентом. По замечанию Н.А. Шматко, «то, что практика производится агентом в рамках объективных и субъективных структур, означает, что она всегда чем-то обусловлена, от чего-то зависит, вытекает из другого» [Шматко 2001, с. 552]. Для категории традиционных вузов в промышленных и нестоличных городах важнейшей предпосылкой появления специфических практик, в которых исполняются нормативно установленные требования приемной кампании, становится дефицит абитуриентов.

Показателем дефицита является индекс выполнения вузами города плановых цифр набора (бюджет+контракт) $\mathbf{I}_{\mathbf{B}}$. Поскольку нормативные требования, опреде-

\footnotetext{
12 Итоговые значения и величина составляющих базовых нормативов затрат на оказание государственных услуг по реализации образовательных программ высшего образования, программ послевузовского профессионального образования в интернатуре и подготовки научных кадров в докторантуре, отраслевые корректирующие коэффициенты и порядок их применения на 2018 год и на плановый период 2019 и 2020 годов (утв. Министерством образования и науки РФ от 17 июля 2017 г. N ВП-46/18вн) // http://www.garant.ru/products/ipo/prime/doc/71632178/).
} 
ляющие качество контингента на этапе набора, относятся преимущественно к абитуриентам очной формы обучения, то $\mathbf{I}_{\mathbf{B}}$ рассчитывается применительно к очной форме обучения по формуле:

$$
\mathbf{I}_{\mathbf{B}}=\mathbf{S} / \mathbf{N} \text {, где: }
$$

$\mathbf{S}$ - потенциальный целевой сегмент абитуриентов вузов города;

$\mathbf{N}$ - плановые цифры набора вузов по очной форме обучения (бюджет+контракт).

Потенциальный целевой сегмент абитуриентов $\mathbf{S}$ вузов ограничивается реализуемыми образовательными программами и географическим распределением абитуриентов.

В Кузбассе по факту сформировались две агломерации, которые объединяют города, расположенные вокруг областного центра Кемерово (север) с численностью населения более 650 тыс. чел. и Новокузнецка (юг) с численностью более 1 млн 300 тыс. чел. На юге области сосредоточены моногорода Новокузнецк, Прокопьевск, Киселевск, Междуреченск, а также Осинники, Мыски, Калтан, основным видом деятельности предприятий которых всегда были угледобыча и металлургия. Подготовку кадров для предприятий и организаций городов юга Кузбасса традиционно осуществляют вузы Новокузнецка, целевым сегментом которых являются выпускники школ юга Кузбасса. Так, за 2014-2017 гг. в Новокузнецкий институт (филиал) Кемеровского государственного университета (далее НФИ КемГУ) с общим контингентом более 6 тыс. студентов были зачислены 65\% выпускников школ Новокузнецка, 30\% - школ городов и районов юга Кузбасса, $1 \%$ - из иных городов Кемеровской области и более $3 \%$ - из других регионов и стран ближнего зарубежья.

Таким образом, потенциальный целевой сегмент абитуриентов вузов города $\mathbf{S}$ численно можно рассчитать по формуле:

$\mathbf{S}=\mathbf{G}_{\mathbf{S}}-\left(\mathbf{G}_{\mathbf{N}}+\mathbf{G}_{\mathrm{A}}\right)$, где:

$\mathbf{G}_{\mathbf{S}}$ - общее количество выпускников школ юга Кузбасса;

$\mathbf{G}_{\mathbf{N}}$ - количество выпускников школ, не планирующих поступление в вуз;

$\mathbf{G}_{\mathbf{A}}$ - количество выпускников школ, чей профессиональный выбор программ высшего образования не соответствует направлениям подготовки, реализуемым в вузах города.

Следует отметить, что дефицит абитуриентов формируется под влиянием объективных и субъективных причин. Речь идет о демографическом факторе, факторе образовательной миграции и институциональном факторе.

Следствием демографических процессов 1990-х и начала 2000-х гг. стало снижение количества обучающихся в системе среднего образования. По данным управлений (комитетов) образования городских округов и муниципальных районов юга Кузбасса, в 2017 г. общее количество выпускников школ Новокузнецка и городов юга Кузбасса составило 4126 чел. ${ }^{13}$ (для сравнения в 2016 г. - 4363 чел.),

13 Справки о выпуске обучающихся школ управлений (комитетов) образования гг. Новокузнецк, Калтан, Киселевск, Междуреченск, Мыски, Прокопьевск, Таштагол и Таштагольский р-н, Новокузнецкий р-н. Период формирования справок - 29.12.2016-15.01.2017 гг. 
высшее образование продолжило 80\% выпускников (3301 чел.). Согласно проведенному опросу, 48\% выпускников школ юга Кузбасса (1584 чел.) отметили, что в Новокузнецке вузы с интересующими их направлениями подготовки отсутствуют. Таким образом, потенциальный целевой сегмент абитуриентов вузов города $\mathbf{S}$ coставил 1717 чел.

На 2017 г. плановый набор вузов (бюджет+контракт) был заявлен в количестве 3780 чел., из них на очную форму обучения - 2050 чел. ${ }^{14}$ Значение индекса выполнения плановых (бюджет+контракт) цифр набора $\mathbf{I}_{\mathbf{B}}$, согласно приведенной формуле, составило 0,84 . Это означает, что в условиях существующей демографии вузы города не выполнили плановый набор на очную форму обучения ввиду физического отсутствия необходимого количества абитуриентов.

Для будущего студента имеют значение не только направление подготовки, имидж вуза, но и социокультурная среда города, где предстоит получать высшее образование. Если вектор образовательного маршрута абитуриентов направлен за пределы родного города и региона, то фактор образовательной миграции, под которой понимаются как внутренние, так и внешние перемещения индивидов с целью получения образования различного уровня, независимо от перспектив последующей миграции или возвращения [Алексеева 2012, с. 116], усиливает демографические риски вузов.

Для Новокузнецка, как образовательного центра юга Кузбасса, наблюдается тенденция массового отъезда выпускников школ. По данным комитета образования и науки Новокузнецка, за четыре года (2013-2017 гг.) количество оставшихся учиться в родном городе сократилось с 63 до 41,1\%, а число уехавших за пределы Кемеровской области выросло с 29,1 до 50,2\%. Аналогичные тенденции наблюдаются и в других городах юга Кузбасса, откуда уезжают в Москву и Санкт-Петербург примерно 25\% выпускников школ, в Новосибирск - около $40 \%$; в Томск - примерно 20\%. По сути, образовательная миграция становится разновидностью интеллектуальной миграции и снижает «входное» качество контингента вузов. В ходе исследования на альтернативный вопрос «В каком городе вы планируете получить высшее образование?» другой город выбрали 70,4\% отличников и $64,5 \%$ обучающихся на «отлично» и «хорошо». Как показали результаты опроса, в стратегии образовательной миграции значение имеют не столько объективные («профессиональный выбор не может быть реализован в вузах города»), сколько субъективные причины, связанные с восприятием города как социокультурного пространства и оценкой качества образования в его вузах. В случае с Новокузнецком был использован метод семантического дифференциала, показавший, что он как город для жизни сместился в негативную шкалу оценок: в частности, критерии, описывающие экологию, характеризовали город как «грязный» и «больной»; семантически он связывался с физической работой, совершенно не ассоциировался с инновационностью, и выпускники школ, планировавшие отъезд, не видели перспектив своего развития в городе - для них город представлялся преимущественно «удушающим», «отсталым», «скучным», «бедным» и «тусклым». Согласно данным Комитета образования и науки администрации Новокузнецка,

\footnotetext{
14 Источник: количество мест на обучение по различным условиям поступления на 2016/2017 уч.г. на официальных сайтах вузов: СибГИУ - http://www.sibsiu; НФИ КемГУ - http://nbikemsu.ru; КузГТУ им. Т.Ф. Горбачева в Новокузнецке - http://kuzstu-nf.ru; Кузбасский институт ФСИН - http://ki.fsin.su
} 
по уровню образовательной миграции значение $\mathbf{I}_{\mathbf{B}}$ снизилось до 0,66. Помимо этого, миграционные установки абитуриентов стимулируют институциональные факторы - возможность поступления в любой вуз по результатам ЕГЭ, а также отсутствие/недостаток бюджетных мест в родном городе по выбранным направлениям подготовки.

Таким образом, приемная кампания вузов реализовывалась на фоне существенного дефицита абитуриентов в количественном и качественном отношениях. В этих условиях способом адаптации вузов к данной ситуации становятся практики приемной кампании, которые призваны решить внутренне противоречивые задачи: с одной стороны, обеспечить численный набор абитуриентов для сохранения образовательной программы и учебной нагрузки профессорско-преподавательского состава, с другой, соблюсти нормативно установленные требования к уровню подготовки абитуриентов и к процедуре набора. Нарушение этих требований для вуза может иметь крайне негативные последствия, определяемые результатами мониторинга или проверки Рособрнадзора.

\section{Практики заполнения бюджетных мест}

Одна из главных задач приемной кампании вуза - это выполнение контрольных цифр приема, структура которых по областям знаний может не совпадать с профессиональной ориентацией абитуриентов. Например, в 2017 г. вузы Новокузнецка предлагали абитуриентам 1250 бюджетных мест, из них 617 на инженерное дело, технологии и технические науки. В то же время, по результатам опроса выпускников школ юга Кузбасса, инженерное дело, технологии и технические науки выбрали лишь 389 чел. (16,3\% респондентов).

Возникает вопрос: каким образом можно заполнить бюджетные места, которые не пользуются популярностью у абитуриента, причем у абитуриента с баллами ЕГЭ не ниже показателя мониторинга Е.1 «Образовательная деятельность»? В ст. 70 Ф3 «Об образовании в Российской Федерации» от 29.12.2012 № 273Ф3 подробно перечисляются категории абитуриентов, которым предоставляется право поступления по результатам вступительных испытаний, форма и перечень которых определяются образовательной организацией высшего образования самостоятельно; помимо этого, вуз вправе самостоятельно устанавливать минимальное количество баллов ЕГЭ при целевом приеме, который проводится в рамках квоты контрольных цифр приема. Это означает, что требования мониторинга по среднему баллу ЕГЭ не предъявляются к иностранным гражданам, лицам, имеющим среднее профессиональное или высшее образование и поступающим по договору о целевом обучении, в связи с чем вуз заинтересован в зачислении именно этих категорий абитуриентов. Например, в Сибирском государственном индустриальном университете (далее - СибГИУ) растет количество обучающихся иностранных граждан из стран ближнего зарубежья (Казахстан, Киргизия, Таджикистан и другие) ${ }^{15}$ : если в 2013 г. значение показателя Е.3 «Международная деятельность» равнялось 3,08\%; то в 2014 г. - 4,98\% (+61,7\% к предыдущему году); в 2015 г. -

15 Показатель «Международная деятельность» не учитывается для филиалов. 
$8,35 \%(+67,7 \%)$; в 2016 г. $-11,5 \%(+37,7 \%)$, а в 2017 г. $-13,6 \%(+18,3 \%)^{16}$. В этот же период студенты, принятые по результатам целевого приема на первый курс на очную форму обучения, составляли среди бюджетников $9,71,10,65,6,45$ и $3,33 \%$ соответственно ${ }^{17}$. Без учета выпускников среднего профессионального образования эти группы абитуриентов (будущих инженеров) зачислялись и обучались без учета качественных характеристик, сфокусированных в баллах ЕГЭ.

Существенным резервом заполнения бюджетных мест являются и абитуриенты с несформированным профессиональным выбором, но с четкой установкой на бесплатное обучение. По результатам опроса, 36,7\% выпускников школ юга Кузбасса готовы были учиться там, куда пройдут на бюджет, если не поступят на бюджетное место выбранной образовательной программы.

В ст. 70 ФЗ «Об образовании в Российской Федерации» также указано, что результаты ЕГЭ при приеме на обучение действительны в течение четырех лет, следующих за годом получения таких результатов. На практике это означает, что на направления подготовки, где имеется дефицит абитуриентов на бюджетные места, могут зачисляться «мертвые души», в число которых также входят студенты младших курсов с соответствующими по набору ЕГЭ сертификатами. При этом студенты могут не догадываться о манипуляциях с их документами.

\section{Практики заполнения контрактных мест}

Переход сферы образования к рыночным отношениям сопровождается сокращением бюджетных мест, и в настоящее время на платное обучение поступает примерно половина абитуриентов. При этом возможность обучения на бюджете в значительной степени зависит от региона, категории вуза и образовательной программы: так, контингент студентов по востребованным направлениям подготовки - юриспруденция, экономика, управление - в большинстве своем формируется контрактниками. Как правило, данные направления с вариациями профилей дублируются в вузах одного города, поэтому за каждого абитуриента идет жесткая конкурентная борьба.

Механизм нормативно-подушевого финансирования вузов, основанный на определении нормативной стоимости обучения одного студента (по очной форме обучения) и финансировании вуза в соответствии с государственным заданием по подготовке специалистов, существенно сокращает возможности вуза набирать контрактных студентов и формировать качественный контингент. Дело в том, что стоимость обучения на контрактной основе не может быть ниже базовой стоимости обучения на бюджетной основе, которая ежегодно корректируется в соответствии с законодательством и с методикой расчета, утверждаемой Минобрнауки РФ.

\footnotetext{
16 Из беседы с преподавателем вуза: «Войдя в аудиторию, начинаешь понимать, насколько тесные контакты у нас сохранились с бывшими республиками СССР».

17 Информационно-аналитические материалы по результатам проведения мониторинга эффективности деятельности образовательных организаций высшего образования. 2015-2017 гг. Сибирский государственный индустриальный университет // https://miccedu.ru/monitoring/2013/materials/inst_272.htm; http://indicators.miccedu.ru/ monitoring/2015/inst.php?id=272; http://indicators.miccedu.ru/monitoring/2016/_vpo/inst.php?id=272; http://indicators. miccedu.ru/monitoring/_vpo/inst.php?id=272
} 
Государство стремится обеспечить качественное оказание услуг посредством применения корректирующих коэффициентов и установления базовых нормативных затрат по стоимостным группам направлений подготовки (специальностям) на относительно высоком уровне. В Кемеровской области для стоимостной группы № 1 оплата за обучение в 2017 г. составляла 107200 руб., для стоимостной группы, где требовалось специальное лабораторное оборудование - 115200 руб. Для набора 2018 г. и плановый период до 2019-2020 гг. продолжается рост базовой стоимости обучения ${ }^{18}$. Это слишком высокая стоимость обучения для родителей абитуриента в регионе, где среднемесячная заработная плата в период приемной кампании в августе 2017 г. составляла 32344 руб. ${ }^{19}$, а реальные денежные доходы населения снижались $\left(96,7 \%\right.$ от показателей предшествующего периода) ${ }^{20}$. В этих условиях аргументом в пользу выбора вуза становится более низкая оплата за обучение, и возникают предпосылки для ценового демпинга.

Следует отметить, что нарушение методики расчета создает условия для недобросовестной конкуренции. По данным сайтов вузов, стоимость обучения за семестр по популярному у абитуриентов направлению подготовки «экономика» имела существенные различия в вузах города: для набора 2016 г. в СибГИУ 31700 руб., в Кузбасском государственном техническом университете в Новокузнецке (далее - КузГТУ) - 35000 руб., в НФИ КемГУ - 53610 руб. ${ }^{21}$. Для набора 2017 г. ситуация частично выправилась, и базовые нормативы были соблюдены всеми вузами, но требования введения корректирующих коэффициентов учитывались не всегда, и как следствие - возникли отличия в стоимости обучения: в СибГИУ - 44800 руб., в КузГТУ - 41000 руб., в НФИ КемГУ - 53610 руб. ${ }^{22}$.

Дополнительным способом привлечения абитуриентов становится система скидок, дифференцированных в зависимости от среднего балла ЕГЭ поступающего, что позволяет увеличить набор на контракт и расширить возможности для платного обучения в родном городе выпускникам школ из семей с невысоким достатком. Но привлекательная для абитуриента ценовая политика вуза отрицательно сказывается на качестве подготовки выпускников. Разница между нормативно установленной и предлагаемой вузом стоимостью обучения - это выпадающие

\footnotetext{
18 Итоговые значения и величина составляющих базовых нормативов затрат на оказание государственных услуг по реализации образовательных программ высшего образования, программ послевузовского профессионального образования в интернатуре и подготовки научных кадров в докторантуре, отраслевые корректирующие коэффициенты и порядок их применения на 2018 г. и на плановый период 2019 и 2020 гг. (утв. Министерством образования и науки РФ от 17 июля 2017 г. N ВП-46/18вн) // http:/www.garant.ru/products/ipo/prime/doc/71632178/

19 Официальный сайт Кемеровостат // http://kemerovostat.gks.ru/wps/wcm/connect/rosstat ts/kemerovostat/resour ces/704e5d0041 fea9b0821 efe 27f9898572/Среднемесячная+начисленная+заработная+плата+работников+организа ций+\%28динамика\% $29 . \mathrm{pdf}$

20 Официальный сайт Кемеровостат // http://kemerovostat.gks.ru/wps/wcm/connect/rosstat_ts/kemerovostat/resourc es/83b091004e9bf6c1a505b7a638e2bbf1/doxod1.htm
}

21 Официальный сайт СибГИУ // http://www.sibsiu.ru/upload/iblock/7cf/prikaz-ob-izmenenii-stoimostiobucheniya-na-pervom-kurse-15_16g..pdf; Официальный сайт КузГТУ им. Т.Ф. Горбачева в Новокузнецке // http://kuzstu-nf.ru/wp-content/uploads/2015/02/stoim_obuch_osen_2015.pdf

22 Официальный сайт СибГИУ. Приказ об установлении полной стоимости платных образовательных услуг для студентов, аспирантов, принимаемых на первый курс 2017/2018 учебного года // http://www.sibsiu.ru/files/abiturientu/2018/ Платное\%20обучение/.pdf; Официальный сайт НФИ КемГУ. Приказ об установлении стоимости платных образовательных услуг на 2017/2018 гг. // http://nbikemsu.ru/sites/files/doc/sved_oo/9.2.1.1.pdf; Официальный сайт филиала Кузбасского государственного технического университета им. Т.Ф. Горбачева в Новокузнецке. Приказ об установлении платных образовательных услуг на 2017/2018 учебный год для 1 курса // http://kuzstu-nf.ru/abitur/stoimost-obucheniya/ 
доходы, которые не могут быть направлены на выполнение требований к условиям реализации образовательной программы, и вуз вынужден сокращать затраты посредством оптимизации учебного процесса: это и комплектация учебных потоков и учебных групп с нормативно допустимой максимальной численностью студентов, корректировка учебных планов. Например, порядок организации и осуществления образовательной деятельности по образовательным программам высшего образования, утвержденный Минобранауки РФ, допускает определение объема контактной работы ${ }^{23}$ организацией самостоятельно ${ }^{24}$. В этом случае при разработке учебного плана возможно снижение объема аудиторной нагрузки, который составляет небольшую часть общей трудоемкости изучаемой дисциплины. В локальных документах вузов города максимальный и минимальный объемы аудиторной работы для очной формы обучения в неделю имеют различия ${ }^{25}:$ НФИ КемГУ 36/12; СибГИУ - 26/12; в филиале КузГТУ - 35/10 академических часов, причем в утвержденном локальными актами диапазоне возможна корректировка объема аудиторной нагрузки в учебном плане ${ }^{26}$.

Перечень вступительных испытаний при приеме на обучение по образовательным программам высшего образования (программам бакалавриата и программам специалитета (с изменениями)) утверждается приказом Минобрнауки РФ, для участия в ЕГЭ абитуриенту нужно до 1 февраля подать заявку. После этого срока заявления принимаются у обучающихся только при наличии уважительных причин и рассматриваются Государственной экзаменационной комиссией РФ. При приеме документов на конкретные направления подготовки вуз руководствуется исключительно утвержденным перечнем ЕГЭ, что для абитуриента означает ограничение свободы профессионального выбора после указанного срока, а для вуза риски набора, привязанные к перечню и результатам сдачи ЕГЭ (суммарный балл).

Для того чтобы в условиях дефицита абитуриентов и активной образовательной миграции в другие города набрать максимальное количество абитуриентов на контрактные места и одновременно выполнить требования мониторинга по среднему баллу ЕГЭ для контрактников необходимы определенные способы адаптации к данной ситуации. Ст. 34 Ф3 «Об образовании в Российской Федерации» от 29.12.2012 № 273-Ф3 обеспечивает право обучающегося на перевод для получения

\footnotetext{
23 Контактная работа может быть аудиторной, внеаудиторной, а также проводиться в электронной информационно-образовательной среде.

24 Приказ Минобрнауки России от 05.04.2017 N 301 «Об утверждении порядка организации и осуществления образовательной деятельности по образовательным программам высшего образования - программам бакалавриата, программам специалитета, программам магистратуры» (пункт 29) // https://gubkin.ru/departaments/educational_activities/umu/files/Prikaz_301_poryadok.pdf

25 Положение о порядке организации и осуществления образовательной деятельности по образовательным программам высшего образования - программам бакалавриата, программам специалитета, программам магистратуры, - утвержденное ректором КемГУ 07.09.2017 г. (пп. 7.23; 7.24) // http://nbikemsu.ru/sites/files/doc/omk/ local/2017_PPD_Porydok_OD_VO_07092017.pdf; Положение об организации образовательной деятельности, утвержденное ректором СибГИУ 30.11 .2017 г. (пп. 4.4; 4.7) // http://oop.sibsiu.ru/download.php?file=fff65228304232 be23c82bb9397f1526; Положение о порядке организации и осуществления образовательной деятельности по образовательным программам высшего образования - программам бакалавриата, программам специалитета, программам магистратуры в КузГТУ, - утвержденное ректором КузГТУ 22.08.2017 г. (п. 7.14) // http://kuzstu-nf.ru/wpcontent/uploads/2017/12/Положение-о-порядке-организации-и-осуществления-образовательной-деятельности.pdf

26 Так, в беседе со студентом и его родителем, которые приняли решение о переводе из одного вуза города в другой, в качестве причины перевода было сказано: «Мы платим деньги не для того, чтобы учиться на очном отделении, как на заочном».
} 
образования по другой профессии, специальности и (или) направлению подготовки, по другой форме обучения в порядке, установленном законодательством об образовании. Это свидетельствует о том, что существуют правовые основания для зачисления абитуриентов на условиях контрактной формы обучения на направление подготовки, которому соответствует имеющийся у абитуриента перечень ЕГЭ, с последующим переводом на выбранную им образовательную программу. Причем зачисление через заочную форму с последующим переводом на очную форму обучения позволяет игнорировать и требования показателя Е.1, которые действуют только для абитуриентов очной формы.

По каждому критерию мониторинга эффективности деятельности вузов установлен норматив, и если выполнены менее четырех показателей из семи, то вуз признается неэффективным, вносится в перечень образовательных организаций, которые в течение ближайшего года проверит Рособрнадзор. Но когда решение проблемы набора абитуриентов (бюджет+контракт) становится условием выживания, то большинство вузов из двух зол выбирают меньшее, т.е. нарушение требований мониторинга по среднему баллу ЕГЭ (таблица 1).

Таблица 1. Позиции вузов по показателю Е.1 «Образовательная деятельность» без учета реорганизованных организаций ВО по результатам мониторинга 2013-2017 гг. $^{27}$

\begin{tabular}{|l|c|c|c|c|c|c|}
\hline \multirow{2}{*}{ Образовательная организация Во } & \multicolumn{5}{|c|}{ Значение показателя } & \multicolumn{2}{|c|}{$\begin{array}{c}\text { Пороговое } \\
\text { значение }\end{array}$} \\
\cline { 2 - 7 } & $\mathbf{2 0 1 3}$ & $\mathbf{2 0 1 4}$ & $\mathbf{2 0 1 5}$ & $\mathbf{2 0 1 6}$ & $\mathbf{2 0 1 7}$ & \\
\hline $\begin{array}{l}\text { Сибирский государственный индустриальный } \\
\text { университет }\end{array}$ & 52,13 & 57,37 & 54,31 & 57,89 & 56,78 & 60 \\
\hline $\begin{array}{l}\text { Новокузнецкий институт (филиал) } \\
\text { Кемеровского госуниверситета }\end{array}$ & 57,33 & 57,58 & 62,01 & 63,2 & 65,06 & 60 \\
\hline $\begin{array}{l}\text { Кузбасский государственный технический } \\
\text { университет им. Т.Ф. Горбачева в Новокузнецке }\end{array}$ & 50,03 & 54,9 & 52,09 & 56,29 & 53,3 & 60 \\
\hline
\end{tabular}

Принимая во внимание результаты мониторинга за предшествующие годы реорганизованных в городе четырех филиалов и вуза (Кузбасская государственная педагогическая академия), можно сделать вывод, что нарушение данной нормы мониторинга превратилось в институализированную практику: в вузы зачисляются абитуриенты независимо от уровня их знаний, профессиональной ориентации, т.е. не имеющие должных характеристик для обучения в вузе. Таким образом, возникшие практики свидетельствуют о деформации института конкурсного отбора, когда нормой становится снижение уровня требований к абитуриенту на этапе приема и зачисления, что порождает следующие системные риски:

\footnotetext{
27 Источники: Информационно-аналитические материалы. Архив материалов за 2013 год // https://miccedu.ru/ monitoring/2013/materials/inst_272.htm; Архив материалов за 2014 год//https:/miccedu.ru/monitoring/2014/materials/ reg_10902.htm; Архив материалов за 2016 год // http://indicators.miccedu.ru/monitoring/2016/index.php?m=vpo; Информационно-аналитические материалы... 2017 год // http://indicators.miccedu.ru/monitoring/?m=vpo
} 
- риски вуза. Снижение требований в процессе набора негативно влияет на репутацию вуза и представления о качестве образования в нем, что усиливает отток талантливой молодежи и проблематизирует очередную приемную кампанию. По результатам опроса выпускников школ юга Кузбасса, на вопрос «Почему Вы хотите получить образование в другом городе?» $48,7 \%$ респондентов ответили, что «образование в вузах других городов более качественное». Такая установка абитуриентов усиливает образовательную миграцию, а сокращение и снижение качества контингента студентов ограничивают профессиональные перспективы преподавателей, стимулируют отток квалифицированных кадров и сопровождается риском потери кадрового потенциала вуза, способного выполнять показатели мониторинга эффективности деятельности вузов, а также требования, которые предъявляются к качеству образования и оцениваются в рамках государственной аккредитации и государственного контроля (надзора) в сфере образования;

- кадровые риски потребителя. Возникшие практики снижают качество набора в вузы и становятся институциональным препятствием для решения приоритетных задач развития системы ВО региона - подготовки кадров для инновационного социально ориентированного развития Кемеровской области ${ }^{28}$. При этом, по оценкам специалистов, руководителей региона и предприятий, с 2000-х гг. область находится в зоне кадровых рисков: в четвертом кластере регионов с низким уровнем человеческого потенциала [Петросяни 2011, с. 29-30] качество кадров стало ограничением для развития базовых отраслей Кузбасса [Козовой 2008, с. 26], инновационного предпринимательства в сфере малого бизнеса [Урбан О.А., Урбан Н.А. 2013, с. 297-298], а качество управления не соответствует инновационным задачам региона ${ }^{29}$.

\section{Заключение}

Возникшие практики набора в вузы можно рассматривать как результат спонтанной адаптации к неблагоприятным условиям дефицита абитуриентов для выполнения плановых цифр набора (бюджет+контракт), сохранения организационной целостности и финансовой устойчивости вуза. На формирование практик оказывает влияние совокупность факторов, а институциональное неравенство вузов, связанное со статусом, определяет уровень их конкурентоспособности и привлекательности для абитуриента. Действие единых правил набора для всех категорий вузов усиливает иерархическую сегрегацию вузов, а ЕГЭ снижает барьеры для поступления в вузы с любым статусом и в любом городе.

Последствия демографического спада усиливает фактор образовательной миграции, в которую включены по большей части профориентированные выпускники школ с высокими баллами ЕГЭ. При этом образовательную миграцию стимулиру-

\footnotetext{
28 Государственная программа Кемеровской области «Развитие системы образования Кузбасса» на 2014-2025 годы (с изменениями на 23 октября 2017 года) утверждена постановлением Коллегии Администрации Кемеровской области от 4 сентября 2013 г. N 367 // http://docs.cntd.ru/document/412804773

29 Тулеев пожаловался на нехватку в Кузбассе управленцев (2017) // Капитал. Бизнес журнал на A42RU. 27 января 2017 // http://biz.a42.ru/lenta/show/tuleev-pozhalovalsya-na-nehvatku-v-kuzbasse-upravlentsev.html
} 
ет отсутствие или недостаток бюджетных мест по востребованным направлениям подготовки в родном городе и поддерживает территориальный фактор, характеризующий неблагоприятные социокультурные, экологические и экономические условия проживания в городе.

Рассматриваемые практики сформировались на основании действующих нормативных документов и частично имеют неправовой характер, так как сопровождаются нарушениями нормативных требований и (или) социокультурных норм, которые связаны с обязательствами вуза относительно качества подготовки перед учредителем, потребителем, абитуриентом и его родителями. Обеспечивая выживаемость вузов в текущем периоде, данные практики являются неэффективным институтом с точки зрения задач региональной системы ВО, так как создают институциональные препятствия для кадрового обеспечения модернизации экономики региона.

Указанные практики не являются локальными, они укоренились в российских вузах дифференцированно в зависимости от статуса, конкурентного потенциала вуза и территории, где расположен вуз. Проблемой становится трансформация сложившихся практик и преодоление их отрицательных последствий, для чего требуется системный подход и реализация комплекса мер всеми заинтересованными сторонами в развитии кадрового потенциала на конкретной территории.

На уровне Минобрнауки РФ. В планировании объема и структуры КЦП для вузов по аккредитованным программам с учетом прогноза кадровых потребностей региональных экономик можно рассмотреть вопрос о дополнительной поддержке вузов по объему и структуре КЦП, деятельность которых имеет существенное значение для территории и сохранения ее кадрового потенциала. Например, сокращение бюджетных мест в НФИ КемГУ по УГНС 44.03 .00 «Образование и педагогические науки» более чем в три раза - с 641 в 2014 г. до 252 для набора 2018 г. - содержит системные риски для региона в целом. Неоспоримо, что подготовка кадров для экономики региона базируется на эффективной подготовке современного учителя. Такое существенное сокращение бюджетных мест в вузе, который традиционно готовит 70\% педагогических кадров в регионе, усилит имеющийся их дефицит в образовательных организациях, особенно в малых городах и сельских местностях: уже сегодня доля учителей в возрасте старше 55 лет в Кемеровской области составляет 23\%; в территориальном аспекте доля учителей пенсионного возраста в небольших городах и сельских поселениях - более $30 \%{ }^{30}$. Между тем, по данным Департамента труда и занятости населения Кемеровской области, в прогнозном периоде до 2023 г. категория педагогических работников станет одной из самых востребованных ${ }^{31}$.

На уровне органов региональной и местной государственной власти. Следует способствовать созданию при вузах структур дополнительного образования детей, целью которых является профессиональная ориентация обучающихся с формированием установки на получение образования в родном городе, регионе и содействие росту кадрового потенциала региона с учетом требований текущих,

\footnotetext{
30 Справка Департамента образования и науки Кемеровской области от 15.02 .2017 г.

31 Прогноз потребности экономики Кемеровской области в квалифицированных кадрах (2017-2023 гг) // Официальный сайт Департамента труда и занятости Кемеровской области // http://www.ufz-kemerovo.ru/home/trudotnosheniay/trudres.aspx, дата обращения 20.01.2018 г.
} 
перспективных задач региональной экономики. Этот процесс требует инвестиций, поэтому важными направлениями взаимодействия органов власти с предприятиями могут стать поиск источников финансирования для создания перечисленных образовательных структур и достижение договоренности о кадровой, материально-технической, финансовой поддержке проектов, направленных на развитие молодежи, в том числе выделение грантов на разработку образовательных программ заинтересованных в них предприятий, также возможно и целевое выделение финансов в рамках региональных, муниципальных программ на реализацию проектов в области обучения, например, предпринимательству.

При этом инициативная и талантливая молодежь (выпускники школ, вузов) вряд ли согласятся остаться учиться и работать там, где отсутствуют комфортные условия жизни и перспективы карьерного роста и самореализации. В этом плане требуются изменение социальных, экологических условий жизни, способных приостановить миграцию молодежи, создание институциональных условий для привлечения потенциальных инвесторов, развивающих новые производства и предлагающих высококвалифицированные рабочие места.

На уровне вуза. Для повышения качества контингента и привлечения абитуриентов целесообразно:

- усилить комплексные мероприятия профессиональной ориентации для обучающихся школ малых городов (в том числе сельских), направленные на формирование лояльности к местным вузам и формирование «своего» абитуриента. Речь идет об открытии на базе вуза лицея, гимназии для учащихся старших классов, профильных классов, школ, творческих объединений, школьных технопарков, центров одаренных детей с профильной ориентацией на направления подготовки вуза, проведение тематических летних лагерей и другие;

- активно реализовывать на основе входного тестирования корректирующие (выравнивающие) мероприятия для студентов первого курса с целью успешного освоения дисциплин (модулей) учебного плана образовательной программы;

- заниматься модернизацией, лицензированием новых образовательных программ с учетом актуальных и перспективных потребностей локального рынка труда, возможностей трудоустройства выпускников на основе развития партнерских отношений с работодателем.

\section{Литература}

Алексеева Е.Н. (2012) Особенности и перспективы образовательной миграции в эпоху глобальных трансформаций // Вестник Московского университета. Серия. 18. Социология и политология. № 4. С. 113-136.

Барсукова С.Ю. (2005) Структура и институты неформальной экономики // Социологический журнал. № 3 С. 118-134.

Барсукова С.Ю. (2011) Теневые правила взаимоотношений политиков и предпринимателей // Журнал институциональных исследований. Т. 3. № 3. С. 40-56.

Барсукова С.Ю. (2006) Власть и бизнес: новые правила игры // Полис. № 6. С. 135-144.

Бессонова О.Э. (2012) Институциональная матрица для модернизации России // Вопросы экономики. № 8. С. 122-144.

Волков В.В. (1997) О концепции практик в социальных науках // Социологические исследования. № 6. С. 9-23. 
Волков В.В., Хархордин О.В. (2008) Теория практик. СПб.: Европейский университет в СПб.

Гидденс Э. (2005) Устроение общества: Очерк теории структурации. М.: Академический Проект.

Заславская Т.И. (2003) Социетальная трансформация российского общества: Деятельностно-структурная концепция. М.: Дело.

Заславская Т.И., Шабанова М.А. (2001) Социальные механизмы трансформации неправовых практик // Общественные науки и современность. № 5. С. 3-22.

Заславская Т.И., Шабанова М.А. (1) (2002) К проблеме институционализации неправовых социальных практик в России: сфера труда // Мир России. Т. 11. № 2. С. 3-38.

Заславская Т.И., Шабанова М.А. (2) (2002) Неправовые трудовые практики и социальные трансформации в России // Социологические исследования. № 2. С. 3-17.

Иванов С.А., Сокол-Номоконов Э.Н. (2018) Феномен опорных университетов региональной экономики в современной России // Высшее образование в России. № 1. С. 19-30.

Кирдина С.Г. (2001) Позволяют ли новые институциональные теории понять и объяснить процессы преобразований в современной России? // Социологические исследования. № 3. C. 136-140.

Кирдина С.Г. (2014) Институциональные матрицы и развитие России: введение в Х-Ү-теорию. СПб.: Нестор-История.

Козина И.П. (1995) Особенности стратегии case study при изучении производственных отношений на промышленных предприятиях России // Социология: методология, методы, математические модели. № 5-6. С. 65-90.

Козовой Г.И. (2008) Доклад «Опыт и перспективы развития угольной компании» на научно-практической конференции, посвященной 35-летию шахты «Распадская» и пятилетию «Распадской угольной компании» // Уголь. № 8. С. 25-26.

Курбатова М.В., Левин С.Н. (2003) Деформализация правил взаимодействия власти и бизнеса // Вопросы экономики. № 10. С. 120-128.

Курбатова М.В., Левин С.Н. (2010) Деформализация правил в современной российской экономике (на примере взаимодействия власти и бизнеса) // Экономический вестник Ростовского государственного университета. Т. 8. № 1. С. 27-50.

Курбатова М.В., Апарина Н.Ф., Каган Е.С. (2009) Выбор работниками способов защиты своих трудовых прав // Социологические исследования. № 7. С. 48-60.

Курбатова М.В., Донова И.В., Каган Е.С. (2017) Оценка изменений положения преподавателей российских вузов // Мир России. № 3. С. 90-116.

Михайлова Е.И., Саввинов В.М. (2016) Университет как институт развития региона // Высшее образование в России. № 10. С. 37-47.

Петросянц Д.В. (2011) Индекс развития человеческого потенциала в субъектах Российской Федерации // Региональная экономика: теория и практика. № 43. С. 23-31.

Прохоров А.В. (2013) Модели университета в условиях глобализации // Известия высших учебных заведений. Поволжский регион. Гуманитарные науки. № 3 (27). С. 56-66.

Ромм М.В., Заякина Р.А. (2016) Сетевые сообщества с участием вуза: сложившиеся практики социального взаимодействия // Высшее образование в России. № 11. С. 28-37.

Сенашенко В.С. (2017) О реформировании отечественной системы высшего образования: некоторые итоги // Высшее образование в России. № 6. С. 5-15.

Урбан О.А. (2010) Социально-трудовые и коллективно-договорные практики в Кузбассе // Труд и социальные отношения. № 11. С. 95-104.

Урбан О.А. (2012) Региональная практика социального партнерства // Труд и социальные отношения. № 11. С. 60-69.

Урбан О.А., Урбан Н.А. (2013) Инновационный потенциал малого бизнеса (по результатам социологического исследования) // Вестник Кемеровского государственного университета. № 1. С. 295-299.

Фадеева О.П. (2015) Сельские сообщества и хозяйственные уклады: от выживания к развитию. Новосибирск: ИЭОПП СО РАН.

Хадасевич Н.Р. (2012) Кадровый потенциал региона РФ как социальный ресурс модернизации экономики // Вестник Санкт-Петербургского университета. Серия 12. Социология. С. 195-200. 
Чубик П.С., Чучалин А.И., Похолков Ю.П., Агранович Б.Л. (2009) Исследовательские университеты в России: пути становления и развития // Университетское управление: практика и анализ. № 1. С. 22-30.

Шабанова М.А. (2006) Экономический и социологический анализ институциональных изменений // Общественные науки и современность. № 6. С. 65-80.

Шибанова Е.К. (2015) Моделирование системы высшего образования: зарубежный опыт и российские тенденции // Современные проблемы науки и образования. № 4 // https://science-education.ru/ru/article/view?id=20877

Шматко Н.А. (2001) На пути к практической теории практики. Послесловие // Бурдье П. Практический смысл. СПб.: Алетейя.

\title{
Social Practices of Maintaining Enrollment at Russian Universities
}

\author{
O. URBAN*
}

\begin{abstract}
*Olga Urban - DSc in Sociology, Associate Professor, Professor of the Department of Sociology and Philosophy, Deputy Director, Head of the Center for Social and Humanitarian Information Technology, Novokuznetsk Institute (branch) of the Kemerovo State University. Address: 23, Tsiolkovskij St., Novokuznetsk, 654041, Russian Federation. E-mail: urban-o@yandex.ru
\end{abstract}

Citation: Urban O. (2019) Social Practices of Maintaining Enrollment at Russian Universities. Mir Rossii, vol.28, no 2, pp. 125-147 (in Russian). DOI: 10.17323/1811-038X-2019-28-2-125-147

\begin{abstract}
The recent modernization of the higher education system in Russia developed a network of universities with special status and financial support. Such universities have become centers of attraction for young people from different regions of the Russian Federation. The focus of this study, however, is on how the universities that do not enjoy such a special status maintain and attract enrollment in such a context. More specifically, the study focuses on the social practices that underpin the process of such enrollment and utilizes the methodological framework for the study of social practices developed by Zaslavskaya.

The study reveals that these universities face problems both with the quality and quantity of applicants. They spontaneously adapt to this situation by recruiting applicants to publicly and privately funded places in order to solve their internal contradictory problems - on one hand, to maintain enrollment in order to preserve an educational program and the teaching load of instructors, while, on the other, complying with regulatory requirements regarding the selection of applicants and the level of their further training. The violation of these requirements can have extremely negative consequences for universities.

By analyzing normative documents, the study further reveals how these practices were formed to ensure the survival of universities. The author argues that existing practices distort competitive selection and create institutional obstacles to the modernization of
\end{abstract}


regional economies by having a detrimental effect on regional human capital. These practices are, in part, of non-legal nature, because they are often accompanied by violations of regulatory requirements and moral obligations of universities to provide quality higher education. The article concludes, however, that the identified practices are not local. They are rooted differentially across Russian universities depending on their status, the competitive potential of universities and where universities operate. Finally, the author elaborates on solutions to transform existing practices in accordance with the goals of regional higher education systems.

Key words: higher education institutions, quality higher education, admission procedures, normative documents, social practices, enrollment, enrollment deficit, student body

\section{Reference}

Alekseeva E. (2012) Osobennosti i perspektivy obrazovatel'noj migratsii v epokhu global'nykh transformatsij [Features and Prospects of Educational Migration in the Era of Global Transformations]. Vestnik Moskjvskogo universiteta. Seriya 18. Sotsiologiya i politologiya, no 4, pp. 113-136.

Barsukova S.Yu. (2005) Struktura i instituty neformal'noj ekonomiki [Structure and Institutions of the Informal Economy]. Sotsiologicheskij zhurnal, no 3, pp. 118-134.

Barsukova S.Yu. (2011) Tenevye pravila vzaimootnoshenij politikov i predprinimatelej [Shadow Rules of the Relationship Between Politicians and Entrepreneurs]. Zhurnal institutsional'nykh issledovanij, vol. 3, no 3, pp. 40-56.

Barsukova S. (2006) Vlast' i biznes: novye pravila igry [Power and Business: the New Rules of the Game]. Polis, no 6, pp. 135-144.

Bessonova O.E. (2012) Institutsional'naya matritsa dlya modernizatsii Rossii [Institutional Matrix for the Modernization of Russia]. Voprosy ekonomiki, no 8, pp. 122-144.

Chubik P.S. Chuchalin A.I., Pokholkov Yu.P., Agranovich B.L. (2009) Issledovatel'skie universitety v Rossii: puti stanovleniya i razvitiya [Research Universities in Russia: Ways of Formation and Development]. Universitetskoe upravlenie: praktika i analiz, no 1, pp. 22-30.

Fadeeva O.P. (2015) Sel'skie soobshchestva i khozyajstvennye uklady: ot vyzhivaniya k razvitiyu [Rural Communities and Economic Ways: from Survival to Development], Novosibirsk: SO RAN.

Giddens E. (2005) Ustroenie obshchestva: Ocherk teorii strukturatsii [Structure of Society: An Outline of Structural Theory], Moscow: Academic Project.

Ivanov S.A., Sokol-Nomokonov E.N. (2018) Fenomen opornykh universitetov regional'noj ekonomiki v sovremennoj Rossii [The Phenomenon of Universities Supporting the Regional Economy in Modern Russia]. Vysshee obrazovanie v Rossii, no 1, pp. 19-30.

Khadasevich N.R. (2012) Kadrovyj potentsial regiona RF kak sotsial'nyj resurs modernizatsii ekonomiki [Regional Human Capital as a Social Resource of Economic Modernization in Russian Regions]. Vestnik Sankt-Peterburgskogo universiteta. Seriya 12. Sociologiya, pp. $195-200$.

Kirdina S.G. (2001) Pozvolyayut li novye institutsional'nye teorii ponyat' i ob'yasnit' protsessy preobrazovanij v sovremennoj Rossii? [Do New Institutional Theories Allow Us to Understand and Explain the Transformation Processes in Modern Russia?]. Sotsiologicheskie issledovaniya, no 3, pp. 136-140.

Kirdina S.G. (2014) Institutsional'nye matritsy i razvitie Rossii: vvedenie v H-Y-teoriyu [Institutional Matrices and the Development of Russia: an Introduction to the X-Y Theory], Saint Petersburg: Nestor-History. 
Kozina I.P. (1995) Osobennosti strategii case study pri izuchenii proizvodstvennykh otnoshenij na promyshlennykh predpriyatiyakh Rossii [Case Study Specifics in the Study of Industrial Relations at Industrial Enterprises in Russia]. Sotsiologiya: metodologiya, metody, matematicheskie modeli, no 5-6, pp. 65-90.

Kozovoj G. (2008) Doklad «Opyt i perspektivy razvitiya ugol'noj kompanii» na nauchnoprakticheskoj konferentsii, posvyashchennoj 35-letiyu shakhty «Raspadskaya» i pyatiletiyu «Raspadskoj ugol'noj kompanii» [The Report "The Experience and Prospects of Development of a Coal Company" presented at the Scientific and Practical Conference Dedicated to the $35^{\text {th }}$ Anniversary of the Raspadskaya Mine and the Fifth Anniversary of the Raspadskaya Coal Company]. Ugol', no 8, pp. 25-26.

Kurbatova M.V., Levin S.N. (2003) Deformalizatsiya pravil vzaimodejstviya vlasti i biznesa [Deformalization of Rules of Interaction between Power and Business]. Voprosy ekonomiki, no 10 , pp. 120-128.

Kurbatova M.V., Levin S.N. (2010) Deformalizatsiya pravil v sovremennoj rossijskoj ekonomike (na primere vzaimodejstviya vlasti i biznesa) [Deformalization of Rules in the Modern Russian Economy (the Case of Interaction between Government and Business)]. Ekonomicheskij vestnik Rostovskogo gosudarstvennogo universiteta, vol. 8, no 1, pp. 27-50.

Kurbatova M.V. Aparina N.F., Kagan E.S. (2009) Vybor rabotnikami sposobov zashchity svoikh trudovykh prav [On the Choice of Ways to Protect Labor Rights from Employees' Point of View]. Sotsiologicheskie issledovaniya, no 7, pp. 48-60.

Kurbatova M.V., Donova I.V., Kagan E.S. (2017) Otsenka izmenenij polozheniya prepodavatelej rossijskikh vuzov [Changes in the Standing of Lecturers at Russian Higher Education Institutions]. Mir Rossii, no 3, pp. 90-116.

Mikhajlova E.I., Savvinov V.M. (2016) Universitet kak institut razvitiya regiona [University as an Institution of Development of the Region]. Vysshee obrazovanie v Rossii, no 10, pp. $37-47$.

Petrosyanz D. (2011) Indeks razvitiya chelovecheskogo potentsiala v sub'ektakh Rossijskoj Federatsii [Human Development Index in the Regions of the Russian Federation]. Regional'naya ekonomika: teoriya i praktika, no 43, pp. 23-31.

Prokhorov A.V. (2013) Modeli universiteta v usloviyakh globalizatsii [Models of Universities in the Conditions of Globalization]. Izvestiya vysshikh uchebnykh zavedenij. Povolzhskij region. Gumanitarnye nauki, no 3 (27), pp. 56-66.

Senashenko V.S. (2017) O reformirovanii otechestvennoj sistemy vysshego obrazovaniya: nekotorye itogi [On the Reform of the National Higher Education System: Some Results]. Vysshee obrazovanie $v$ Rossii, no 6, pp. 5-15.

Shabanova M.A. (2006) Ekonomicheskij i sotsiologicheskij analiz institutsional'nykh izmenenij [Economic and Sociological Analysis of Institutional Changes]. Obshchestvennye nauki i sovremennost', no 6, pp. 65-80.

Shibanova E.K. (2015) Modelirovanie sistemy vysshego obrazovaniya: zarubezhnyj opyt i rossijskie tendentsii [Modeling Higher Education System: Foreign Experience and Russian Trends]. Sovremennye problemy nauki $i$ obrazovaniya, no 4. Available at: https://science-education.ru/ru/article/view?id=20877, accessed 31.01.2019.

Shmatko N.A. (2001) Na puti k prakticheskoj teorii praktiki. Posleslovie [Towards the Practical Theory of Practice. An Afterword]. Burd'e P. Prakticheskij smysl [Practical Sense], Saint Petersburg, pp. 548-562.

Urban O. A. (2010) Sotsial'no-trudovye i kollektivno-dogovornye praktiki v Kuzbasse [Social Practices of Industrial Relations in Kuzbass]. Trud $i$ sotsial'nye otnosheniya, no 11, pp. 95-104.

Urban O.A. (2012) Regional'naya praktika sotsial'nogo partnerstva [The Regional Practice of Social Partnership]. Trud i sotsial'nye otnosheniya, no 11, pp. 60-69.

Urban O. A. and Urban N.A. (2013) Innovatsionnyj potentsial malogo biznesa (po rezul'tatam sotsiologicheskogo issledovaniya) [The Innovative Potential of Small Business (Findings from a Sociological Study)]. Vestnik Kemerovskogo gosudarstvennogo universiteta, no 1, pp. 295-299.

Volkov V.V. (1997) O kontseptsii praktik v sotsial'nykh naukakh [On the Concept of Practices in Social Sciences]. Sotsiologicheskie issledovaniya, no 6, pp. 9-23. 
Volkov V.V., Harhordin O.V. (2008) Teoriya praktik [Theory of Practices], Saint Petersburg: European University in Saint Petersburg.

Zaslavskaya T. (2003) Sotsietal'naya transformatsiya rossijskogo obshchestva: Deyatel'nostnostrukturnaya kontseptsiya [The Societal Transformation of Russian Society: Activitystructural Concept], Moscow: Delo.

Zaslavskaya T.I., Shabanova M.A. (2001) Sotsial'nye mekhanizmy transformatsii nepravovykh praktik [Social Mechanisms of Transformation of Non-legal Practices]. Obshchestvennye nauki i sovremennost', no 5, pp. 3-22.

Zaslavskaya T.I., Shabanova M.A. (1) (2002) K probleme institutsionalizatsii nepravovykh sotsial'nykh praktik v Rossii: sfera truda [On the Problem of Institutionalization of Illegal Social Practices in Russia: the Sphere of Labor]. Mir Rossii, vol. 11, no 2, pp. 3-38.

Zaslavskaya T.I., Shabanova M.A. (2) (2002) Nepravovye trudovye praktiki i sotsial'nye transformatsii v Rossii [Non-legal Labor Practices and Social Transformations in Russia]. Sotsiologicheskie issledovaniya, no 2, pp. 3-17. 